\title{
Indolin-2-ones with High in Vivo Efficacy in a Model for Multiple Sclerosis
}

Laëtitia Bouérat*, J ef Fensholdt, Xifu Liang, Sophie Havez, Simon F. Nielsen, J ens R. Hansen, Simon Bolvig, and Christina Andersson*

LEO Pharma A/ S Industriparken,55, DK-2750 Ballerup, Denmark.

Contents

\begin{tabular}{|c|c|}
\hline Chemistry & S2-S7 \\
\hline General procedure A & $\mathrm{S} 2$ \\
\hline General procedure B & $\mathrm{S} 2$ \\
\hline Synthesis and description of compound $\mathbf{3}$ & S2-S3 \\
\hline Synthesis and description of compound 4 & S3 \\
\hline Synthesis and description of compound $\mathbf{5}$ & S3 \\
\hline Synthesis and description of compound 7 & $\mathrm{~S} 4$ \\
\hline Synthesis and description of compound $\mathbf{8}$ & $\mathrm{S} 4$ \\
\hline Synthesis and description of compound $\mathbf{1 0}$ & S4-S5 \\
\hline Synthesis and description of compound $\mathbf{1 1}$ & S5 \\
\hline Synthesis and description of compound $\mathbf{1 2}$ & S5-S6 \\
\hline Synthesis and description of compound $\mathbf{1 3}$ & S6 \\
\hline Synthesis and description of compound $\mathbf{1 5}$ & S6-S7 \\
\hline Synthesis and description of compound $\mathbf{1 8}$ & $\mathrm{S} 7$ \\
\hline Synthesis and description of compound 19 & S7 \\
\hline Pharmacology : in vitro and in vivo models & S8-S10 \\
\hline In vitro assays & S8-S9 \\
\hline Il-2 PBMC assay & $S 8$ \\
\hline KDR assay & $S 8-S 9$ \\
\hline EAE model & S9-S10 \\
\hline Materials and methods & $S 9-S 10$ \\
\hline Results for compound $\mathbf{1}$ & $S 10$ \\
\hline
\end{tabular}


For ${ }^{1} \mathrm{H}$ nuclear magnetic resonance (NMR) spectra (300 MHz) and ${ }^{13} \mathrm{C}$ NMR (75.6 MHz) chemical shift values

$(\delta)$ (in ppm) are quoted for dimethyl- $d_{6}$ sulfoxide $\left(\mathrm{DMSO}-d_{6}\right)$ solutions relative to internal tetramethylsilane $(\delta=$ $0)$ standard. The value of a multiplet, either defined (doublet (d), triplet (t), quartet (q)) or multiplet (m) at the approximate mid point is given. (br) indicates a broad singlet.

The described indolin-2-ones can exist in two isomer forms: the $Z$ and the $E$ isomer forms. The NMR data characterize the isomer forms that are present in the solvent used to record the NMR spectrum. For NMR solutions where the equilibrium is shifted in favour of one isomer form, the chemical shifts of the dominating form are given.

The accurate mass measurements were obtained on a VG AutoSpec mass spectrometer equiped with an EI source. The instrument was operated at a resolution of 10000 FWHM.

The organic solvents used were anhydrous unless otherwise specified. Flash chromatography was performed on silica gel 60 (0.040-0.063) purchased from Merck.

\section{General procedure A:}

A solution of an aldehyde (1 eq.), 1,3-dihydro-indol-2-one (1 eq.), and piperidine (catalytic amount) in EtOH is heated under reflux overnight. The crude mixture is allowed to warm to rt and cooled in an ice bath. A precipitate is obtained, which is filtered and washed with cold EtOH. If no precipitation occurs, the solvent is removed and the residue is purified by flash chromatography.

\section{General procedure B:}

To a suspension or solution of the starting pyrrole ( 1 eq.) in $\mathrm{CCl}_{4}$ is added NBS (1.05 eq.), followed by benzoylperoxide (0.025 eq.) under argon. The mixture is then heated under reflux and the reaction is followed by LC/MS. The crude mixture is then allowed to warm to rt and cooled in an ice bath. A precipitate is filtered and purified by flash chromatography. If no precipitation occurs the solvent is removed under reduced pressure and the crude is purified by flash chromatography.

4-Bromo-3,5-dimethyl-1H-pyrrole-2-carbaldehyde (3)

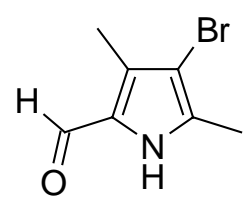

Compound 3 was obtained following general procedure B using compound 2 (3,5-dimethyl- $1 H$-pyrrole-2carbaldehyde, $8 \mathrm{~g}, 65$ mmoles), NBS (12.16 g, 68.3 mmoles) and benzoyl-peroxide (394 mg, $1.63 \mathrm{mmoles})$ in 
$\mathrm{CCl}_{4}(300 \mathrm{~mL})$. After purification by flash chromatography (EtOAc/Petroleum ether, 30:70), compound 3 was obtained as a dark solid (11.9 g, 92\% yield).

${ }^{1} \mathrm{H}$ NMR (DMSO-d $) \delta 12.06$ (br, 1H), 9.50 (s, 1H), 2.22 (s, 3H), 2.19 (s, 3H).

3-(4-Bromo-3,5-dimethyl-1H-pyrrol-2-ylmethylene)-1,3-dihydro-indol-2-one (4)

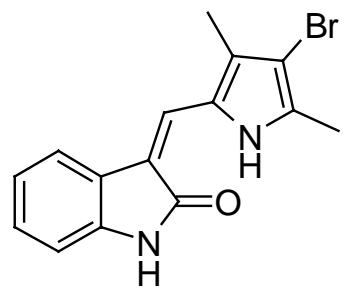

Compound 4 was obtained following general procedure B using compound 1 (3-(3,5-dimethyl-1H-pyrrol-2ylmethylene)-1,3-dihydro-indol-2-one, $2 \mathrm{~g}, 8.4$ mmoles), NBS (1,57 g, $8.8 \mathrm{mmoles})$, and benzoyl-peroxide (0.05 $\mathrm{g}, 0.21 \mathrm{mmoles})$ in $\mathrm{CCl}_{4}(80 \mathrm{~mL})$. Crystallization from dioxane lead to compound $\mathbf{4}$ as an orange/brown powder (0.7 g, 26\% yield).

Compound 4 could also be obtained following general procedure A using compound $\mathbf{3}$ (0.21 g, $1 \mathrm{mmole}), 1,3$ dihydro-indol-2-one (0.14 g, 1 mmole) and piperidine $(63 \mu \mathrm{L})$ in EtOH (3.5 mL). After filtration, compound 4 was obtained as an orange/brown powder $(0.3 \mathrm{~g}, 92 \%$ yield $)$.

${ }^{1} \mathrm{H}$ NMR (DMSO- $d_{6}, Z$-isomer) $\delta 13.79$ (s, 1H), 10.90 (s, 1H), 7.77 (d, 1H), 7.63 (s, 1H), $7.14(\mathrm{t}, 1 \mathrm{H}), 6.99$ (t, $1 \mathrm{H}), 6.88(\mathrm{~d}, 1 \mathrm{H}), 2.32(\mathrm{~s}, 3 \mathrm{H}), 2.28(\mathrm{~s}, 3 \mathrm{H})$.

HRMS: calcd for $\mathrm{C}_{15} \mathrm{H}_{13} \mathrm{BrN}_{2} \mathrm{O}, 316.0211$; found 316.0223.

3-(4-Chloro-3,5-dimethyl-1 H-pyrrol-2-ylmethylene)-1,3-dihydro-indol-2-one (5)

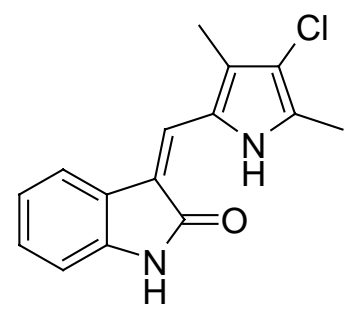

To a suspension of compound 1 (3-(3,5-dimethyl-1H-pyrrol-2-ylmethylene)-1,3-dihydro-indol-2-one, 2 g, 8.4 mmoles $)$ in dry $\mathrm{CH}_{2} \mathrm{Cl}_{2}(30 \mathrm{~mL})$ was added under argon at $0^{\circ} \mathrm{C}$ sulfonyl chloride $(0.84 \mathrm{~mL}, 8.4$ mmoles $)$. The dark mixture was left under stirring at $0^{\circ} \mathrm{C}$ for $70 \mathrm{~min}$ and then allowed to warm to rt for $15 \mathrm{~min}$. Removal of the solvent and purification by flash chromatography (using a gradient of petroleum ether/EtOAc from 90:10 to 50:50) gave compound 5 as an orange solid $(0.77 \mathrm{~g}, 34 \%$ yield $)$.

${ }^{1} \mathrm{H}$ NMR (DMSO- $d_{6}, Z$-isomer) $\delta 13.72(\mathrm{~s}, 1 \mathrm{H}), 10.90(\mathrm{~s}, 1 \mathrm{H}), 7.77(\mathrm{~d}, 1 \mathrm{H}), 7.61(\mathrm{~s}, 1 \mathrm{H}), 7.13(\mathrm{t}, 1 \mathrm{H}), 7.00(\mathrm{t}$, $1 \mathrm{H}), 6.88(\mathrm{~d}, 1 \mathrm{H}), 2.32(\mathrm{~s}, 3 \mathrm{H}), 2.28(\mathrm{~s}, 3 \mathrm{H})$.

HRMS: calcd for $\mathrm{C}_{15} \mathrm{H}_{13} \mathrm{ClN}_{2} \mathrm{O}, 272.0704$; found 272.0716. 
3-(3,5-Dimethyl-1H-pyrrol-2-ylmethylene)-1-hydroxy-1,3-dihydro-indol-2-one (7)

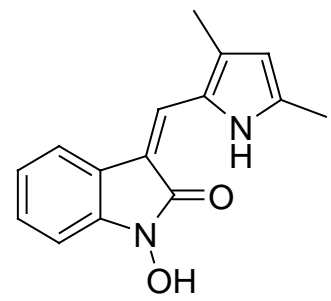

Compound 7 was obtained following general procedure A using compound 6 (1-hydroxy-1,3-dihydro-indol-2one, $0.09 \mathrm{~g}, 0.6$ mmoles), compound 2 (3,5-dimethyl-1H-pyrrole-2-carbaldehyde, $0.07 \mathrm{~g}, 0.6 \mathrm{mmoles}$ ) and piperidine $(37 \mu \mathrm{L})$ in EtOH $(2 \mathrm{~mL})$. Filtration gave compound 4 as a dark solid $(0.13 \mathrm{~g}, 87 \%$ yield $)$.

${ }^{1} \mathrm{H}-\mathrm{NMR}$ (DMSO- $d_{6}, Z$-isomer) $\delta 13.22(\mathrm{br}, 1 \mathrm{H}), 10.84(\mathrm{br}, 1 \mathrm{H}), 7.78(\mathrm{~d}, 1 \mathrm{H}), 7.61(\mathrm{~s}, 1 \mathrm{H}), 7.19(\mathrm{t}, 1 \mathrm{H}), 7.03(\mathrm{t}$, $1 \mathrm{H}), 6.98(\mathrm{~d}, 1 \mathrm{H}), 6.02(\mathrm{~s}, 1 \mathrm{H}), 2.34(\mathrm{~s}, 3 \mathrm{H}), 2.31(\mathrm{~s}, 3 \mathrm{H}),{ }^{13} \mathrm{C}-\mathrm{NMR}$ (DMSO- $d_{6}, Z$-isomer) $\delta 163.1,137.4,136.2$, $132.3,126.3,125.7,123.8,121.4,121.0,117.7,112.6,109.0,106.5,13.4,11.2$.

HRMS: calcd for $\mathrm{C}_{15} \mathrm{H}_{14} \mathrm{~N}_{2} \mathrm{O}_{2}, 254.1055$; found 254.1029.

Acetic acid 3-(3,5-dimethyl-1H-pyrrol-2-ylmethylene)-2-oxo-2,3-dihydro-indol-1-yl ester (8)

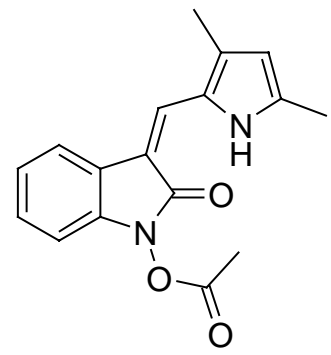

To a suspension of compound 7 (0.41 g, 1.64 mmoles) in acetonitrile $(12 \mathrm{~mL})$ were added acetic anhydride $(2.5$ $\mathrm{mL}$ ) and triethylamine $(2.5 \mathrm{~mL})$. The resulting solution was stirred for $1 \mathrm{~h}$ at rt. Concentration in vacuo and purification by flash chromatography (using a gradient of petroleum ether/EtOAc from 100:0 to 85:15) afforded compound 8 (0.35 g, $71 \%$ yield $)$.

${ }^{1} \mathrm{H}$ NMR $\left(d_{6}\right.$-DMSO, Z-isomer) $\delta 12.77(\mathrm{~s}, 1 \mathrm{H}), 7.87(\mathrm{~d}, 1 \mathrm{H}), 7.72(\mathrm{~s}, 1 \mathrm{H}), 7.20(\mathrm{t}, 1 \mathrm{H}), 7.12(\mathrm{t}, 1 \mathrm{H}), 7.04(\mathrm{~d}, 1 \mathrm{H})$, $6.08(\mathrm{~d}, 1 \mathrm{H}), 2.45(\mathrm{~s}, 3 \mathrm{H}), 2.34(\mathrm{~s}, 6 \mathrm{H})$.

HRMS: calcd for $\mathrm{C}_{17} \mathrm{H}_{16} \mathrm{~N}_{2} \mathrm{O}_{3}, 296.1161$; found 296.1139.

5-Formyl-4-methyl-1H-pyrrole-2-carboxylic acid ethyl ester (10)

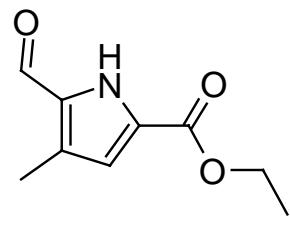


To a solution of (chloro-methylen)-dimethyl-ammonium-chloride (1.64 g, 12.8 mmoles) in dry DCE (6 mL) was added dropwise under argon atmosphere a solution of 9 (4-methyl-1 $H$-pyrrole-2-carboxylic acid ethyl ester, 1.31 $\mathrm{g}, 8.6 \mathrm{mmoles}$ ) in 1,2-dichloroethane (DCE, $5 \mathrm{~mL}$ ). The reaction mixture was heated slightly to dissolve all solid material and stirred at $\mathrm{rt}$ overnight. The $\mathrm{pH}$ of the reaction mixture was adjusted to 10 by addition of $\mathrm{NaOH}(2 \mathrm{~N})$. The crude mixture was extracted with $\mathrm{CH}_{2} \mathrm{Cl}_{2}(3 \times 10 \mathrm{~mL})$. The combined organic phases were washed once with $\mathrm{H}_{2} \mathrm{O}$, once with brine, dried over $\mathrm{MgSO}_{4}$, and filtered. After removal of the solvent, compound $\mathbf{1 0}$ was obtained as a pale red/orange solid and used in the next step without further purification (1.49 g, 99\% yield).

${ }^{1} \mathrm{H}$ NMR (DMSO-d $\left.)_{6}\right) 12.6(\mathrm{br}, 1 \mathrm{H}), 9.80(\mathrm{~s}, 1 \mathrm{H}), 6.70(\mathrm{~s}, 1 \mathrm{H}), 4.27(\mathrm{q}, 2 \mathrm{H}), 2.30(\mathrm{~s}, 3 \mathrm{H}), 1.30(\mathrm{t}, 3 \mathrm{H})$.

4-Methyl-5-(2-oxo-1,2-dihydro-indol-3-ylidenemethyl)-1H-pyrrole-2-carboxylic acid ethyl ester (11)

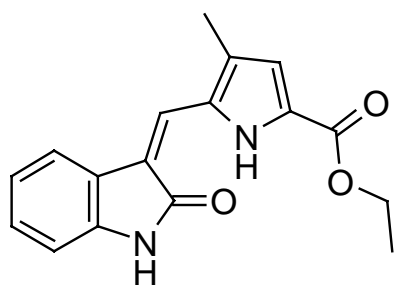

Compound 11 was prepared following general procedure A using compound 9 (5-formyl-4-methyl-1H-pyrrole-2carboxylic acid ethyl ester, $0.93 \mathrm{~g}, 7$ mmoles), 1,3-dihydro-indol-2-one (1.27 g, 7 mmoles), and piperidine (few drops) in $\mathrm{EtOH}$ (25 mL). Filtration gave compound 11 as orange crystals (1.98 g, 99\% yield).

${ }^{13}$ C-NMR (DMSO- $d_{6}, Z$-isomer) $\delta 169.0,159.7,139.4,129.9,128.8,128.0,124.5,124.3,122.5,121.4,120.7$, 119.6, 116.4, 109.7, 60.3, 14.2, 11.0.

HRMS: calcd for $\mathrm{C}_{17} \mathrm{H}_{16} \mathrm{~N}_{2} \mathrm{O}_{3}, 296.1161$; found 296.1142 .

3-(5-Hydroxymethyl-3-methyl-1H-pyrrol-2-ylmethylene)-1,3-dihydro-indol-2-one (12)

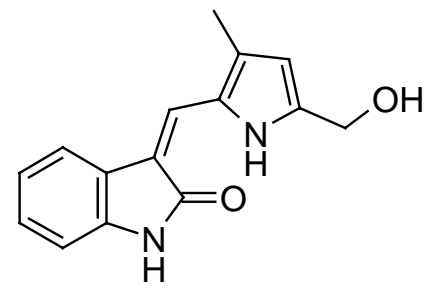

To a dry solution of compound $\mathbf{1 1}(1 \mathrm{~g}, 3.38 \mathrm{mmoles})$ in toluene $(20 \mathrm{~mL})$ was added under $\operatorname{argon}$ and at $-78^{\circ} \mathrm{C}$ a 1 M solution of DIBAL-H in toluene (34 mL). The reaction was followed by TLC. After $1.5 \mathrm{~h}$, extra amount (17 $\mathrm{mL}$ and $10 \mathrm{~mL}$ ) of DIBAL-H (1 M in toluene) was added at $-78^{\circ} \mathrm{C}$ and the temperature was allowed to raise to $40^{\circ} \mathrm{C}$. $\mathrm{MeOH}(60 \mathrm{~mL})$ was added at $-75^{\circ} \mathrm{C}$ and the mixture was allowed to come to rt. After addition of saturated aqueous $\mathrm{NH}_{4} \mathrm{Cl}$ solution $(40 \mathrm{~mL})$, the crude mixture was extracted with EtOAc $(3 \times 60 \mathrm{~mL})$. The combined organic phases were washed once with $\mathrm{H}_{2} \mathrm{O}$, once with brine, and dried over $\mathrm{MgSO}_{4}$. After filtration and removal of the 
solvent, followed by crystallization from EtOAc and petroleum ether, compound $\mathbf{1 2}$ was obtained as orange crystals $(0.58 \mathrm{~g}, 68 \%$ yield $)$.

${ }^{1} \mathrm{H}-\mathrm{NMR}$ (DMSO- $d_{6}, Z$-isomer) $\delta 13.42(\mathrm{~s}, 1 \mathrm{H}), 10.75(\mathrm{~s}, 1 \mathrm{H}), 7.72(\mathrm{~d}, 1 \mathrm{H}), 7.58(\mathrm{~s}, 1 \mathrm{H}), 7.11(\mathrm{t}, 1 \mathrm{H}), 6.97(\mathrm{t}$, $1 \mathrm{H}), 6.87(\mathrm{~d}, 1 \mathrm{H}), 6.07(\mathrm{~d}, 1 \mathrm{H}), 5.38(\mathrm{br}, 1 \mathrm{H}), 4.53(\mathrm{~s}, 2 \mathrm{H}), 2.32(\mathrm{~s}, 3 \mathrm{H}) ;{ }^{13} \mathrm{C}-\mathrm{NMR}$ (DMSO- $d_{6}, Z$-isomer) $\delta 169.2$, $140.0,138.3,130.7,126.4,125.9,125.7,123.3,120.7,118.1,113.6,110.2,109.2,56.6,11.3$.

HRMS: calcd for $\mathrm{C}_{15} \mathrm{H}_{14} \mathrm{~N}_{2} \mathrm{O}_{2}, 254.1055$; found 254.1036.

4-Methyl-5-(2-oxo-1,2-dihydro-indol-3-ylidenemethyl)-1H-pyrrole-2-carboxylic acid (13)

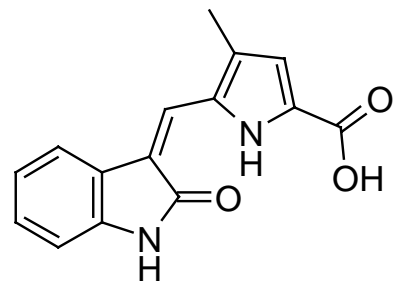

A solution of compound 11 (2.8 g, 9.5 mmoles) in a 1:1 mixture of THF (150 mL) and an aqueous solution of $\mathrm{LiOH}(1 \mathrm{~N}, 150 \mathrm{~mL})$ was heated under reflux for $4 \mathrm{~h}$.. The $\mathrm{pH}$ was adjusted to 6-7 by addition of an aqueous solution of $\mathrm{HCl}(1 \mathrm{~N}$, about $150 \mathrm{~mL})$. A bright orange precipitate was filtered to afford compound $\mathbf{1 3}$ as an orange solid (2.47 $\mathrm{g}, 97 \%$ yield).

${ }^{1} \mathrm{H}-\mathrm{NMR}$ (DMSO- $d_{6}, Z$-isomer) $\delta 13.86(\mathrm{br}, 1 \mathrm{H}), 10.95$ (br, 1H), $7.82(\mathrm{~d}, 1 \mathrm{H}), 7.67(\mathrm{~s}, 1 \mathrm{H}), 7.21(\mathrm{t}, 1 \mathrm{H}), 7.03$ (t, $1 \mathrm{H}), 6.92(\mathrm{~d}, 1 \mathrm{H}), 6.74(\mathrm{~s}, 1 \mathrm{H}), 2.35(\mathrm{~s}, 3 \mathrm{H}) ;{ }^{13} \mathrm{C}-\mathrm{NMR}$ (DMSO- $d_{6}, Z$-isomer) $\delta$ 169.2, 161.3, 139.6, 129.7, 129.0, $128.0,125.6,124.8,122.7,121.5,120.5,119.6,116.4,109.8,11.1$.

HRMS: calcd for $\mathrm{C}_{15} \mathrm{H}_{12} \mathrm{~N}_{2} \mathrm{O}_{3}, 268.0848$; found 268.0833.

4-Methyl-5-(2-oxo-1,2-dihydro-indol-3-ylidenemethyl)-1H-pyrrole-2-carboxylic acid (2-hydroxy-ethyl)-amide (15)

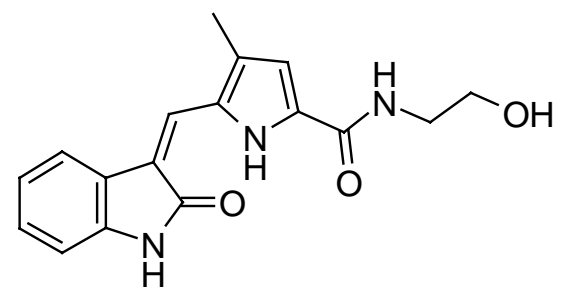

A mixture of compound 11 (0.46 g, 1.57 mmoles), $\mathrm{K}_{2} \mathrm{CO}_{3}$ (0.35 g, $\left.2.52 \mathrm{mmoles}\right)$, and ethanolamine (28 mL, 466 mmoles) in acetonitrile $(14 \mathrm{~mL})$ was heated at $105^{\circ} \mathrm{C}$ for $1 \mathrm{~h}$.. The mixture was allowed to come to rt, poured into $\mathrm{H}_{2} \mathrm{O}$, and extracted with EtOAc $(3 \times 20 \mathrm{~mL})$. The combined organic phases were washed once with $\mathrm{H}_{2} \mathrm{O}$, once with brine and dried over $\mathrm{MgSO}_{4}$. After filtration and removal of the solvent, compound $\mathbf{1 5}$ was obtained as an orange solid (0.42 g, $85 \%$ yield). 
${ }^{1} \mathrm{H}$ NMR (DMSO- $d_{6}, Z$-isomer) $\delta 13.64(\mathrm{~s}, 1 \mathrm{H}), 10.89(\mathrm{br}, 1 \mathrm{H}), 8.32(\mathrm{t}, 1 \mathrm{H}), 7.80(\mathrm{~d}, 1 \mathrm{H}), 7.64(\mathrm{~s}, 1 \mathrm{H}), 7.18(\mathrm{t}$, 1H), $7.01(\mathrm{t}, 1 \mathrm{H}), 6.88(\mathrm{~d}, 1 \mathrm{H}), 6.83(\mathrm{~d}, 1 \mathrm{H}), 4.73(\mathrm{t}, 1 \mathrm{H}), 3.50(\mathrm{~m}, 2 \mathrm{H}), 3.3(\mathrm{~m}, 2 \mathrm{H}), 2.35(\mathrm{~s}, 3 \mathrm{H})$.

HRMS: calcd for $\mathrm{C}_{17} \mathrm{H}_{17} \mathrm{~N}_{3} \mathrm{O}_{3}, 311.1270$; found 311.1246 .

3-(1H-Indol-3-ylmethylene)-1,3-dihydro-indol-2-one (18)

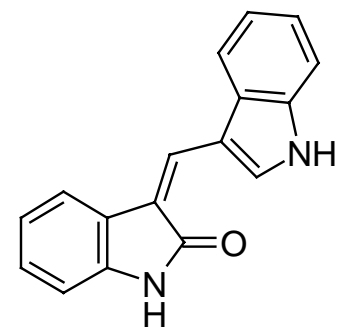

Compound 18 was prepared following general procedure A using $1 H$-indole-3-carbaldehyde $(1.7 \mathrm{~g}, 11 \mathrm{mmoles})$, 1,3-dihydro-indol-2-one (1.5 g, 7 mmoles), and piperidine (46 drops) in EtOH (45 mL). After filtration, compound 18 was obtained as orange crystals ( $2.8 \mathrm{~g}, 96 \%$ yield $)$.

${ }^{1} \mathrm{H}$ NMR (DMSO- $d_{6}, Z$-isomer) $\delta 12.01$ (br, 1H), 10.52 (s, 1H), 9.48 (s, 1H), 8.19 (d, 1H), 8.17 (s, 1H), 7.89 (d, 1H), $7.54(\mathrm{~m}, 1 \mathrm{H}), 7.3-7.2(\mathrm{~m}, 2 \mathrm{H}), 7.15(\mathrm{t}, 1 \mathrm{H}), 7.00(\mathrm{t}, 1 \mathrm{H}), 6.87(\mathrm{~d}, 1 \mathrm{H}) ;{ }^{1} \mathrm{H}$ NMR (DMSO- $d_{6}, E$-isomer) $\delta$ $12.01(\mathrm{br}, 1 \mathrm{H}), 10.52(\mathrm{~s}, 1 \mathrm{H}), 8.25(\mathrm{~s}, 1 \mathrm{H}), 7.92(\mathrm{~s}, 1 \mathrm{H}), 7.78(\mathrm{~d}, 1 \mathrm{H}), 7.67(\mathrm{~d}, 1 \mathrm{H}), 7.54(\mathrm{~m}, 1 \mathrm{H}), 7.3-7.2(\mathrm{~m}$, $4 \mathrm{H}), 6.93(\mathrm{t}, 1 \mathrm{H})$.

HRMS: calcd for $\mathrm{C}_{17} \mathrm{H}_{12} \mathrm{~N}_{2} \mathrm{O}, 260.0950$; found 260.0932 .

4-Methyl-5-(2-oxo-1,2-dihydro-indol-3-ylidenemethyl)-1H-pyrrole-2-carboxylic acid ethyl ester (19)

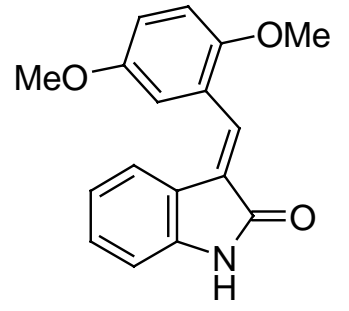

Compound 19 was prepared following general procedure A using 2,5-dimethoxybenzaldehyde (33 g, 197 mmoles), 1,3-dihydro-indol-2-one (26 g, $195 \mathrm{mmoles})$, and piperidine (12 mL) in $\mathrm{EtOH}(600 \mathrm{~mL})$. After filtration, compound 19 was obtained as orange crystals ( $44 \mathrm{~g}, 80 \%$ yield).

${ }^{1} \mathrm{H}$ NMR (DMSO- $d_{6}, E$-isomer) $\delta 10.60(\mathrm{~s}, 1 \mathrm{H}), 7.65(\mathrm{~s}, 1 \mathrm{H}), 7.47(\mathrm{~d}, 1 \mathrm{H}), 7.23(\mathrm{~m}, 2 \mathrm{H}), 7.10(\mathrm{~d}, 1 \mathrm{H}), 7.06(\mathrm{~d}$, $1 \mathrm{H}), 6.89(\mathrm{~m}, 2 \mathrm{H}), 3.81(\mathrm{~s}, 3 \mathrm{H}), 3.75(\mathrm{~s}, 3 \mathrm{H}) ;{ }^{13} \mathrm{C}-\mathrm{NMR}$ (DMSO-d,$E$-isomer) $\delta 168.6,152.5,151.8,142.8,131.4$, $129.9,127.5,123.3,122.4,121.0,121.0,116.8,114.4,112.6,110.0,55.9,55.5$.

HRMS: calcd for $\mathrm{C}_{17} \mathrm{H}_{15} \mathrm{NO}_{3}, 281.1052$; found 281.1063. 


\section{Pharmacology : in vitro and in vivo models}

In vitro assays

\section{IL-2 PBMC assay}

Peripheral blood mononuclear cells (PBMCs) were isolated from human blood. The lymphocytes, a fraction of the PBMCs, were activated to secrete IL-2 using the polyclonal mitogen phytohemagglutinin. The compounds to be tested were dissolved in DMSO at $10 \mathrm{mM}$, stored at $-20^{\circ} \mathrm{C}$ and protected from light. The test compounds were added to the cells in concentrations from $10^{-5}$ to $10^{-10} \mathrm{M}$ and stimulated with PHA to give a final concentration of $10^{6}$ cells $/ \mathrm{mL}$ and $13 \mu \mathrm{g} / \mathrm{mL}$ of PHA in a total volume of $320 \mu \mathrm{L} /$ well. The microtiter plates were incubated at $37^{\circ} \mathrm{C}$ for approximately $46 \mathrm{~h}$. Each concentration of test compound was tested in triplicates.

After $46 \mathrm{~h}$ the cells were centrifuged down for $25 \mathrm{~min}$ at $1000 \mathrm{xg}$ and the supernatants were transferred to microtiter wells precoated with a monoclonal antibody against human IL-2. The IL-2 concentration in the supernatants was determined by a sandwich ELISA. Microtiter plates were coated $(1 \mu \mathrm{g} / \mathrm{mL}, 100 \mu \mathrm{L} / \mathrm{well})$ with a monoclonal antibody (R\&D, UK) against human IL-2, washed 4 times, blocked with $1 \%$ casein buffer for $2 \mathrm{~h}$ and washed twice. $100 \mu \mathrm{L}$ sample was added to each well and incubated overnight. $100 \mu \mathrm{L}$ IL-2 standards (R\&D, $\mathrm{UK}$ ) at a concentration range of $10000-0 \mathrm{pg} / \mathrm{mL}$ were tested in triplicate. After incubation the plates were washed and incubated with biotinylated polyclonal secondary antibody $(3 \mu \mathrm{g} / \mathrm{mL}, 100 \mu \mathrm{L} /$ well $)$ against human IL-2 (R\&D, UK) for 45 min and thereafter washed 4 times. $100 \mu \mathrm{L}$ enzyme conjugate, horseradish peroxidase conjugated streptavidin diluted 1:4000 (Zymed, USA), was added to all wells and incubated for 30 min. $100 \mu \mathrm{L}$ TMB substrate (KEM EN TEC-DK) was added and the enzyme/substrate reaction stopped after 30 min at rt with $100 \mu \mathrm{L} 1 \mathrm{M} \mathrm{H}_{2} \mathrm{SO}_{4}$. The colour development (optical density - OD) was determined at $492 \mathrm{~nm}$ on an ELISA reader and the background OD at $620 \mathrm{~nm}$ subtracted).

The results are expressed as a percentage of the control (PHA + DMSO) and the potency of the test compound was expressed as the concentration resulting in $50 \%$ inhibition of the response of the control stimulated cells $\left(\mathrm{IC}_{50}\right)$.

\section{KDR assay}

The compounds to be tested were dissolved in DMSO at $10 \mathrm{mM}$, stored at $-20^{\circ} \mathrm{C}$ and protected from light. The maximum concentration of DMSO in the in vitro assay was $0.1 \%$. Control samples received the same concentration of solvent as the samples treated with the test compounds. 
For the kinase assays, black 96 wells MaxiSorp microtiter plates were coated by an overnight incubation with 100 $\mu \mathrm{L} /$ well of a $2.5 \mu \mathrm{g} / \mathrm{mL}$ solution of phospholipase $\mathrm{C} \gamma$ in TBS buffer $(40 \mathrm{mM}$ Tris-HCl, $\mathrm{pH}$ 7.4, $20 \mathrm{mM}$ $\left.\mathrm{Mg}\left(\mathrm{C}_{2} \mathrm{H}_{3} \mathrm{O}_{2}\right)_{2}, 0.02 \% \mathrm{NaN}_{3}\right)$ at $4^{\circ} \mathrm{C}$. The plates were washed 3 times with TBS buffer containing $0.1 \%$ Tween-20, and the residual binding sites were masked by incubation with $1 \%$ BSA in TBS buffer containing $0.1 \%$ Tween-20 for $1 \mathrm{~h}$. The plates were washed again and the test compounds were added at final concentrations up to $10 \mu \mathrm{M}$, together with ATP at the final concentration of $100 \mu \mathrm{M}$ in $50 \mu \mathrm{L}$ TBS buffer / well. Then, $50 \mu \mathrm{L}$ of the human intracellular domain of KDR (VEGF Receptor-2) finally diluted 3000-3500-fold were added and were incubated for $30 \mathrm{~min}$ at room temperature. The plates were washed and $100 \mu \mathrm{L}$ of the Europium labelled PY-20 antiphosphotyrosine antibody (Wallac, FIN) were incubated in each well at the concentration of approximately 114 $\mathrm{ng} / \mathrm{mL}$ for $2 \mathrm{~h}$. Then, the plates were washed and $100 \mu \mathrm{L}$ of enhancer solution (Wallac, FIN) were incubated in each well for $5 \mathrm{~min}$ in the dark. The plates were read in a Victor ${ }^{2} 1420$ multilabel counter, using a Europium protocol for time-resolved fluorometry (Wallac, FIN): excitation $340 \mathrm{~nm}$, emission $615 \mathrm{~nm}$, sample pulse cycle $400 \mu$ s. Fluorescence was measured for $400 \mu$ s between flashes after a delay time of $400 \mu \mathrm{s}$. The background measured in the absence of enzyme was subtracted from all samples. The molar concentrations that inhibited 50\% of the maximal enzymatic activity $\left(\mathrm{IC}_{50}\right)$ were calculated from the dose-response curve, by fitting a straight line between the two concentrations immediately above and below the $50 \%$ inhibition point (i.e. by solving the equation $\mathrm{y}=\mathrm{a}+\mathrm{bx})$.

EAE model

\section{Materials and methods}

Peptide The following peptide from myelin proteolipid protein was used; PLP ${ }_{139-153}$ H-HCLGKWLGHPDKFVGOH. The peptide was synthesized by Fmoc chemistry (Schafer-N, Copenhagen, Denmark). Purity (>95\%) was verified by reversed-phase HPLC and integrity by mass spectrometry.

Mice Female SJL/J $\left(\mathrm{H}-2^{\mathrm{S}}\right)$ inbred mice purchased from Charles River or Taconic M\&B

Immunization The SJL/J mice (about 8 weeks old) were immunized on day 0 with the $\mathrm{PLP}_{139-153}$ peptide (dissolved in sterile $\mathrm{NaCl}$ ) emulsified 1:1 (vol/vol) in Complete Freund's Adjuvant (5 mg Mycobacterium tuberculosis/ml) (SSI, Copenhagen, Denmark). Intradermal injections corresponding to $100 \mu \mathrm{g}$ peptide and 125 $\mu \mathrm{g}$ Mycobacterium tuberculosis were given at the base of the tail in a total volume of $50 \mu \mathrm{L}$. The mice were additionally given an i.v. injection with $100 \mathrm{ng}$ pertussis toxin (Sigma) dissolved in sterile $\mathrm{NaCl}$ on day 0 and day 2 , injection volume was $100 \mu \mathrm{L}$. 
Compound treatment Groups of 10 mice were dosed daily with compounds (50 mg/kg) in suspension vehicle (4 g Tween-80, 2 g Carboxy-methyl cellulose 7H4XF, $8 \mathrm{~g} \mathrm{NaCl}, 1$ liter $\mathrm{H}_{2} \mathrm{O}$ ), starting on day 0 (i.p.) or 1 (p.o.).

Control groups were given either suspension vehicle (i.p.) or dexamethasone (p.o., $1 \mathrm{mg} / \mathrm{kg}$ ) (Dexadreson Vet, Intervet, Holland).

Clinical evaluation Mice were weighed and assessed clinically daily from day 5 p.i. according to the following criteria: 0 , no disease; 1 , tail paralysis; 2 , clumsy gait/poor righting ability and limb weakness; 3 , moderate or total hind limb paralysis; 4 , moribund state or dead.

Statistics Area-under-curve (AUC) of the disease score was calculated for all mice. The medians of AUC of all groups were compared using Kruskal-Wallis test. When $\mathrm{P}<0.05$ in the Kruskal-Wallis test, the Mann-Whitney test was used to compare drug treated groups with the suspension vehicle treated control group $(\mathrm{P}<0.05)$. AUCs were calculated from day 0 to the termination of the experiment (day 21).

In vivo results for compound $\mathbf{1}$ :

\section{EAE score}

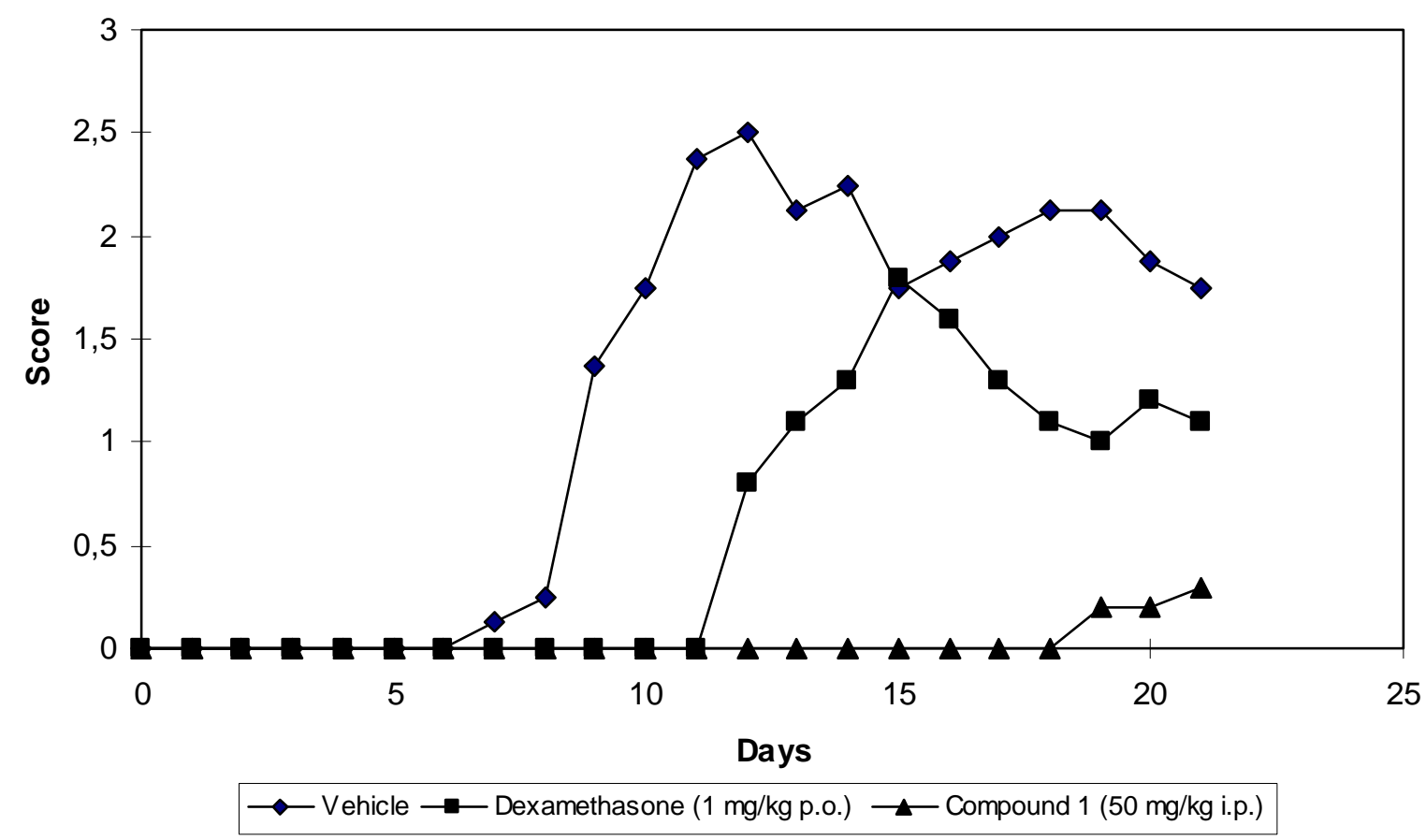

